\title{
Chemical Profile, Antioxidant and Alpha-Amylase Inhibitory Activity of Leaves Extracts of Annona muricata: A Combined In vitro and In silico Study
}

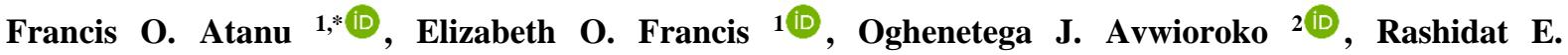 \\ Ibrahim $^{1(\mathbb{D}}$, Blessing I. Adaji ${ }^{1}(\mathbb{D})$, Faith I. Amos ${ }^{1}\left(\mathbb{D}\right.$, Faith O. Ikoja ${ }^{1}{ }^{\mathbb{D}}$, Hauwa E. Ibrahim ${ }^{1}$ \\ 1 Department of Biochemistry, Faculty of Natural Sciences, Kogi State University, Anyigba, P.M.B. 1008, Anyigba, Nigeria \\ 2 Department of Biochemistry, Faculty of Basic Medical Sciences, Redeemer's University, Ede, Osun State, Nigeria \\ * Correspondence: atanufo@gmail.com (F.O.A.); atanu.fo@ksu.edu.ng (F.O.A.);
}

Scopus Author ID 57192130699

Received: 24.06.2021; Revised: 25.07.2021; Accepted: 29.07.2021; Published: 5.09.2021

\begin{abstract}
Leaves of Annona muricata are commonly used for treating diabetes. This study was conducted to investigate the molecular mechanisms involved in the antidiabetic properties of leaves of Annona muricata. Leaves of Annona muricata were extracted separately with $\mathrm{H}_{2} \mathrm{O}$, hydromethanol (50\% methanol), methanol, ethylacetate, and n-butanol. Chemical characterization of the extracts was performed by spectrophotometry and Gas chromatography-Mass Spectrometry (GC-MS) techniques. Biological activity was determined by $\alpha$-amylase inhibition assays and molecular docking. The hydromethanol extract had a total phenolics concentration of $117.00 \pm 0.59 \mu \mathrm{g} \mathrm{GAE} / \mathrm{mg}$ extract whereas; flavonoids were most abundant in the n-butanol extract accounting for 29.34 $\pm 8.87 \mu \mathrm{g} \mathrm{QE} / \mathrm{mg}$ extract. The n-butanol extract had the best FRAP value of $41.17 \pm 0.57$ Vit $C$ eqv $\mathrm{mM}$, which was significantly higher than the value of the vitamin $\mathrm{C}$ reference. Estimated $\mathrm{IC}_{50}$ for all the extracts did not differ significantly but was significantly higher than the reference compound quercetin. All extracts inhibited $\alpha$-amylase in vitro albeit significantly lower than acarbose. The hydromethanol extract had the highest inhibitory activity $(53.31 \pm 0.33 \%)$. Furthermore, chemical profiling of the hydromethanol extract revealed the presence of a variety of bioactive compounds. In silico analysis by molecular docking of the compounds identified by GC-MS on $\alpha$-amylase revealed that the compounds had robust molecular interactions orchestrated by $\mathrm{H}$-bonding and hydrophobic interactions. From the results, it can be concluded that extracts of Annona muricata possess antioxidant phytochemicals that inhibit $\alpha$-amylase. Therefore, the results justify the use of the plant for the treatment of diabetes.
\end{abstract}

Keywords: diabetes mellitus; Annona muricata; alpha-amylase; phytochemical.

(C) 2021 by the authors. This article is an open-access article distributed under the terms and conditions of the Creative Commons Attribution (CC BY) license (https://creativecommons.org/licenses/by/4.0/).

\section{Introduction}

Diabetes mellitus (DM) is non-communicable, characterized by a hyper-level of blood glucose which becomes known after a diagnosis [1, 2]. The World Health Organization (WHO) had opined that despite being a non-infectious disease, DM is a leading cause of death globally, with about 1.5 million deaths associated with the disease in 2019 [3, 4]. Several approaches had been adopted over the decades by researchers towards curbing or treating this disease. Based on the fact that two main types of DM exist [1,5], type 1 DM (also known as Insulindependent diabetes mellitus) and type 2 DM (generally regarded as Non-insulin-dependent diabetes mellitus), therapeutic approaches used over the years have therefore focused on 
different research niches $[1,6]$. For type $1 \mathrm{DM}$, approaches such as insulin injection therapy, insulin receptor activation, insulin gene therapy had been tried amongst others, whereas for type $2 \mathrm{DM}$, the focus had been on the discovery of possible hypoglycemic agents targeted at reducing blood glucose levels to normal concentrations. Hence, orthodox drugs such as glibenclamide, acarbose, vildagliptin, voglibose, miglitol, metformin, and herbal extracts with bioactive compounds had been reported in the management of type 2 diabetes mellitus [7-11]. It is now common knowledge that the mechanism of action of some of these therapeutic agents used for the treatment of type $2 \mathrm{DM}$ is by inhibition of one or more carbohydrate-hydrolyzing enzymes such as alpha-amylase, alpha-glucosidase, sucrase, etc., with the most commonly targeted enzymes being alpha-amylase and alpha-glucosidase [5, 12]. Alpha-amylases belong to the class of hydrolases, which hydrolyze $\alpha-1,4-$ glycosidic bonds in polysaccharides (such as starch, cellulose) to disaccharides and simple sugars [13, 14]. In type 2 DM, a sudden upsurge in blood glucose level in diabetic patients following a meal rich in carbohydrates (a condition referred to as postprandial hyperglycemia) is a major cause of untimely death. This is, however, prevented by the administration of drugs (e.g., acarbose, Glucobay, Precose) or herbal extracts that have inhibitory effects on $\alpha$-amylase activity [8-11]. Inhibition of $\alpha$-amylase helps suppress the rate of breakdown of carbohydrates in the meal, thereby slowing down the release of simple sugars into the bloodstream and preventing postprandial hyperglycemia [7, 13]. One of the side-effects of some orthodox drugs used in the past had been excessive inhibition of the carbohydrate-hydrolyzing enzymes, which in turn leads to abdominal discomfort and flatulence. Hence, since the last few decades, research is now being shifted to sourcing for enzyme inhibitors $[7,15]$ from natural sources (including plant extracts) for safer management of type 2 diabetes [7, 8].

Annona muricata (A. muricata), a plant species that belongs to the family of Annonaceae, is mostly found in the tropics and is well known for its various ethnomedicinal values [16]. The plant is traditionally used to treat insomnia, headache, malaria, diabetes, prostate enlargement, and as an antitumor $[16,17]$. Most of these health benefits can be attributed to the plant's phytochemical composition [18-20]. There is, however, a limited volume of information associating the mechanism of action of A. muricata leaves (regarding its use in the management of type $2 \mathrm{DM}$ ) with alpha-amylase inhibition as well as the possible interaction of its phytochemical components with amino acid residues at the catalytic site of $\alpha$ amylase, especially concerning bioactive components of plant extracts from species located in Nigeria, West Africa. Hence, in the present study, we comparatively investigated the inhibitory effects of various extracts (aqueous, hydromethanol, methanol, ethyl acetate, and n-butanol extracts) of $A$. muricata leaves on alpha-amylase activity and their relative antioxidant capacities. Further, we characterized the most bioactive extract of $A$. muricata leaves using Gas Chromatography-Mass Spectrometry (GC-MS) to identify the phytochemical compounds present that are responsible for its bioactivity. A detailed investigation of the potential interaction of the identified phyto-compounds with amino acid residues at the active site domain of pancreatic $\alpha$-amylase was also carried out using molecular docking techniques.

\section{Materials and Methods}

\subsection{Plant material: collection, processing, and extraction.}

Leaves of Annona muricata were collected from Anyigba Town, Kogi State, Nigeria, and authenticated by the Department of Plant Science and Biotechnology, Kogi State 
University, Anyigba. The leaves were washed, dried at room temperature, and grounded into fine powder. Five portions of $100 \mathrm{~g}$ of leaf powder of Annona muricata were weighed and suspended in $500 \mathrm{~mL}$ of the following solvents: water, $50 \%$ methanol (hydromethanol), methanol, ethylacetate, and n-butanol. The solvent extraction continued for $48 \mathrm{hr}$ followed by filtration using Whatman No 1 filter paper. The filtrate was evaporated to give the solid extract.

\subsection{Quantitative test for total phenolics.}

The total phenol content of Annona muricata extracts was determined according to the method of Singleton et al. [21]. $2.5 \mathrm{ml}$ of $10 \%$ Folin-Ciocalteau's reagent was added to dilutions of the plant extracts, mixed, and neutralized by adding $2.0 \mathrm{~mL}$ of $7.5 \%$ sodium carbonate. After incubating the mixture for $40 \mathrm{~min}$ at $8^{\circ} \mathrm{C}$, the absorbance was measured spectrophotometrically at $765 \mathrm{~nm}$. A calibration curve was plotted using gallic acid was plotted. The results were presented as gallic acid equivalent (mg GAE/g extract).

\subsection{Quantitative test for total flavonoids.}

The total flavonoid content of Annona muricata was determined by using the aluminum chloride's colorimetric assay method described by Bourhia et al. [22]. $1.5 \mathrm{~mL}$ of $2 \% \mathrm{AlCl}_{3}$ was added to dilutions of the plant extracts, mixed, and incubated for $60 \mathrm{~min}$ at room temperature. The absorbance was read using a spectrophotometer. The results were expressed as quercetin equivalent per gram of extract $(\mathrm{mg} \mathrm{QE} / \mathrm{g})$.

\subsection{Ferric ion reducing antioxidant power.}

The methods of Benzie and Strain [23] were used to measure the Ferric reducing antioxidant power (FRAP) of the extracts. Briefly, $0.1 \%$ of plant extract was mixed with $4 \mathrm{~mL}$ FRAP reagent (10:1:1 ratio of acetate buffer $300 \mathrm{mM}$ pH 3.6 : TPTZ [2,4,6,-tripyridyl-striazine] $10 \mathrm{mM}$ in $40 \mathrm{mM} \mathrm{HCl}: \mathrm{FeCl}_{3} \cdot 6 \mathrm{H}_{2} \mathrm{O}$ ). The mixture was incubated in the water bath at $37^{\circ} \mathrm{C}$ for 5 minutes, and absorbance was taken at $593 \mathrm{~nm}$. Ascorbic acid reference was prepared in the same manner. Given that FRAP value of Vit $\mathrm{C}=2.0$ (equivalent to $28.39 \mathrm{mM}$ ) [24], FRAP value of samples were calculated as follows:

FRAP value $=($ Change in sample absorbance $/$ Change in Reference absorbance $) \times 2.0$.

\subsection{DPPH radical scavenging activity.}

The Blois [25] method was using or the measurement of DPPH scavenging activity of the extracts. The assay is based on the ability of samples to donate hydrogen atoms and decolorize methanol solution of 2,2-diphenyl-1-picrylhydrazyl (DPPH). Antioxidants cause a change in the colors of DPPH from violet/purple to yellow. Briefly, $2.4 \mathrm{~mL}$ of $0.1 \mathrm{mM}$ solution of DPPH in methanol was added to $1.6 \mathrm{~mL}$ of different concentrations of the plant extract or quercetin $(6.25-1000 \mu \mathrm{g} / \mathrm{mL})$. The mixture was vortexed and left in the dark at room temperature for $30 \mathrm{~min}$. Absorbance was after that measured spectrophotometrically at $517 \mathrm{~nm}$. Percentage DPPH radical scavenging activity was calculated by the following equation:

$$
\% \text { DPPH radical scavenging activity }=\frac{\left(\mathrm{ABS}_{\text {reference }}-\mathrm{ABS}_{\text {sample }}\right)}{A B S_{\text {reference }}} \times 100
$$

$\mathrm{IC}_{50}$ was derived from a plot of percentage inhibition against the concentration of the sample. 


\section{6. $\alpha$-Amylase inhibition assay.}

In vitro inhibition of $\alpha$-amylase activity was accessed by the method described by Adefegha and Oboh [26] with slight modification. Briefly, $100 \mu \mathrm{L}$ of $0.5 \%$ of plant extract was mixed with equal volume of alpha-amylase [EC 3.2.1.1, $1.0 \mathrm{mg} / \mathrm{mL}$, prepared with $20 \mathrm{mM}$ sodium phosphate buffer ( $\mathrm{pH}$ 6.9) with $0.006 \mathrm{M}$ sodium chloride] and incubated at $25^{\circ} \mathrm{C}$ for $10 \mathrm{~min}$. At the expiration of the $10 \mathrm{~min}, 100 \mu \mathrm{L}$ of $1 \%$ starch solution (prepared in $20 \mathrm{mM}$ sodium phosphate buffer, $\mathrm{pH}$ 6.9) was added and incubated at $25^{\circ} \mathrm{C}$ for 30 min before adding $100 \mu \mathrm{L}$ of dinitrosalicylic acid color reagent to stop the reaction. After that, the mixture was incubated in a boiling water bath for $5 \mathrm{~min}$ and cooled to room temperature. Absorbance was recorded at $540 \mathrm{~nm}$ against a distilled water blank. Acarbose was used as a reference and was assayed in a similar manner [26]. The alpha-amylase inhibitory activity was calculated using the formula:

$$
\text { Percentage inhibition }(\%)=\frac{\left(\mathrm{ABS}_{\text {reference }}-\mathrm{ABS}_{\text {sample }}\right)}{\mathrm{ABS}_{\text {reference }}} \times 100
$$

\subsection{Gas chromatography-mass spectrometry analysis.}

Gas chromatography-mass spectrometry (GC-MS) analysis was carried out on the hydromethanolic extract of Annona muricata. The column temperature was set at $150-250^{\circ} \mathrm{C}$ at a flow rate of $79.5 \mathrm{~mL} / \mathrm{min}$. The eluates from $\mathrm{GC}$ were passed to the mass spectrometer to determine the mass spectral pattern. Identification of the eluted compounds was made by matching the Retention time, fragmentation pattern, and mass spectral data with the National Institute of Standard Technology (NIST) library database.

\subsection{In silico analysis.}

Investigation into the molecular interactions between $\alpha$-amylase and compounds from Annona muricata was carried out using AutoDock Tool v1.5.6. The three-dimensional crystal structures of pancreatic $\alpha$-amylase PBD ID: 5F0F were downloaded from the RCSB Protein Data Bank. Ligand structures were sketched and optimized by ChemDraw. The ligands were docked against $\alpha$-amylase using the grid box size 80 X 74 X $68 \AA$ in the $\mathrm{x}, \mathrm{y}$, and z dimensions with $0.375 \AA$ spacing. PyMol was used to view the molecular interaction, while Discovery Studio software was used to analyze the protein-ligand interactions.

\subsection{Statistical analysis.}

GraphPad InStat version 3.05 was used for data analysis. Values are reported as mean \pm standard deviation (SD) of three determinations. Data were analyzed by one-way analysis of variance (ANOVA) using the Tukey post hoc test. Values were considered statistically significant when $p<0.05$.

\section{Results and Discussion}

\subsection{Results.}

The total phenolic and flavonoid contents of solvent extracts of Annona muricata are presented in Table 1. The highest phenolic content was obtained from the hydromethanol extract $117.00 \pm 0.59 \mu \mathrm{g} \mathrm{GAE} / \mathrm{mg}$ extract. Flavonoids were the best extract, with butanol 
accounting for the total flavonoid content of $29.34 \pm 8.87 \mu \mathrm{g}$ QE/mg extract. Results of in vitro antioxidant activity of the extracts measured using the FRAP and DPPH radical scavenging method is shown in Table 2. The FRAP value of the butanol extract $(41.17 \pm 0.57 \mathrm{Vit} \mathrm{C}$ eqv $\mathrm{mM}$ ) was the highest and significantly higher than the reference compound, Vitamin $\mathrm{C}$ (28.39 \pm 0.00 Vit $\mathrm{C}$ eqv $\mathrm{mM})$. The DPPH radical scavenging capacity $\left(\mathrm{IC}_{50}\right)$ of all the extracts did not differ significantly (ranged between $51.92 \pm 1.42-54.29 \pm 3.13 \mu \mathrm{g} / \mathrm{mL}$ ) but were significantly higher than the reference compound quercetin $(35.67 \pm 0.29 \mu \mathrm{g} / \mathrm{mL})$.

Table 1. Total Phenolics and flavonoid concentration of Annona muricata leave extract

\begin{tabular}{l|c|c} 
Extract & $\begin{array}{c}\text { Total Phenolic } \\
(\mu \mathrm{g} \text { GAE/mg extract) }\end{array}$ & $\begin{array}{c}\text { Total Flavonoid } \\
(\boldsymbol{\mu g} \text { QE/mg extract) }\end{array}$ \\
\hline Aqueous & $67.71 \pm 8.00^{\mathrm{a}}$ & $10.17 \pm 1.69^{\mathrm{a}}$ \\
\hline Hydromethanol & $117.00 \pm 0.59^{\mathrm{b}}$ & $13.13 \pm 1.67^{\mathrm{b}}$ \\
\hline Methanol & $92.54 \pm 3.67^{\mathrm{c}}$ & $12.04 \pm 2.82^{\mathrm{c}}$ \\
\hline Ethylacetate & $40.39 \pm 2.74^{\mathrm{d}}$ & $20.35 \pm 1.80$ \\
\hline n-Butanol & $40.21 \pm 2.55^{\mathrm{d}}$ & $29.34 \pm 8.87^{\mathrm{a}, \mathrm{b}, \mathrm{c}}$
\end{tabular}

Values are expressed as mean \pm SD of three determinations. ${ }^{\mathrm{a}-\mathrm{d}}$ Different superscript letters for a given value within a column are significantly different from each other, $\mathrm{p}<0.05$.

Table 2. Antioxidant activity of extracts from leaves of Annona muricata.

\begin{tabular}{l|c|c} 
Sample/Extract & FRAP Value $($ Vit C eqv in $\mathbf{~ M M})$ & DPPH scavenging activity $\left(\mathbf{I C}_{\mathbf{5 0}} \boldsymbol{\mu \mathbf { g }} / \mathbf{m L}\right)$ \\
\hline Reference & $28.39 \pm 0.00^{\mathrm{a}}$ & Quercetin: $35.67 \pm 0.29$ \\
\hline Aqueous & $23.00 \pm 0.43^{\mathrm{b}}$ & $51.92 \pm 1.42^{\mathrm{e}}$ \\
\hline Hydromethanol & $27.40 \pm 2.13^{\mathrm{a}}$ & $54.29 \pm 3.13^{\mathrm{e}}$ \\
\hline Methanol & $36.77 \pm 0.43^{\mathrm{c}}$ & $51.96 \pm 4.39^{\mathrm{e}}$ \\
\hline Ethylacetate & $39.18 \pm 2.13^{\mathrm{c}, \mathrm{d}}$ & $52.73 \pm 2.50^{\mathrm{e}}$ \\
\hline n-Butanol & $41.17 \pm 0.57^{\mathrm{d}}$ & $53.65 \pm 2.07^{\mathrm{e}}$
\end{tabular}

Values are expressed as mean \pm SD of three determinations. ${ }^{\mathrm{a}-\mathrm{d}}$ Different superscript letters for a given value within a column are significantly different from each other; ${ }^{e}$ significantly different from Quercetin, $\mathrm{p}<0.05$.

Antidiabetic activity measured by the ability of the extracts to inhibit $\alpha$-amylase revealed that aqueous and hydromethanol extracts possessed the highest inhibitory activity; $48.84 \pm 0.23 \%$ and $53.31 \pm 0.33 \%$, respectively. The inhibitory activity of the two extracts did not differ significantly but were both significantly lower than values obtained for the reference drug acarbose $(87.24 \pm 1.76 \%)$ (Table 3 ). The results of the GC-MS analysis shown in table 4 reveals that the hydromethanolic extract is rich in fatty acids, including n-Decanoic acid, Oleic Acid, n-Hexadecanoic acid, and other phytochemicals of medicinal value. These phytochemicals were found to interact with pancreatic $\alpha$-amylase in silico with binding affinity ranging between $4.1-8.7 \mathrm{kcal} / \mathrm{mol}$ (Table 4 and Figure 1). The molecular interactions involved both H-bonding and hydrophobic interactions, as shown in Figure 1.

Table 3. Alpha-amylase inhibitory activity of extracts from leaves of Annona muricata.

\begin{tabular}{l|c} 
Sample/Extract & Inhibition of $\boldsymbol{\alpha}$-amylase activity $\mathbf{( \% )}$ \\
\hline Acarbose & $87.24 \pm 1.76^{\mathrm{a}}$ \\
\hline Aqueous & $48.84 \pm 0.23^{\mathrm{b}}$ \\
\hline Hydromethanol & $53.31 \pm 0.33^{\mathrm{b}}$ \\
\hline Methanol & $43.01 \pm 0.87^{\mathrm{c}}$ \\
\hline Ethylacetate & $14.00 \pm 3.35^{\mathrm{d}}$ \\
\hline n-Butanol & $25.49 \pm 3.44^{\mathrm{e}}$
\end{tabular}

Values are expressed as mean $\pm \mathrm{SD}$ of three determinations. a-e Different superscript letters for a given value within a column are significantly different from each other, $\mathrm{p}<0.05$. 
Table 4. Interaction of compounds identified by GC-MS analysis of hydromethanolic extract of Annona muricata assessed by molecular docking.

\begin{tabular}{|c|c|c|c|c|c|c|}
\hline Compound & $\begin{array}{c}\text { Retention } \\
\text { time }\end{array}$ & Compound name & $\%$ Area & $\begin{array}{c}\text { Chemical } \\
\text { formula }\end{array}$ & $\begin{array}{c}\text { Molecular } \\
\text { weight }(\mathrm{g} / \mathrm{mol})\end{array}$ & $\begin{array}{c}\text { Binding affinity } \\
(\mathrm{kcal} / \mathrm{mol})\end{array}$ \\
\hline 1 & 14.929 & n-Decanoic acid & 0.32 & $\underline{\mathrm{C}}_{10} \underline{\mathrm{H}}_{20} \underline{\mathrm{O}}_{2}$ & 172.26 & -4.1 \\
\hline 2 & 14.952 & Oleic Acid & 0.06 & $\mathrm{C}_{18} \mathrm{H}_{34} \mathrm{O}_{2}$ & 282.50 & -4.5 \\
\hline 3 & 14.998 & 1-Eicosene & 0.09 & $\underline{\mathrm{C}}_{20} \underline{\mathrm{H}}_{40}$ & 280.50 & -4.2 \\
\hline 4 & 15.100 & n-Hexadecanoic acid & 0.23 & $\underline{\mathrm{C}_{16} \mathrm{H}_{32} \mathrm{O}_{2}}$ & 256.42 & -3.5 \\
\hline 5 & 15.177 & Octadecanoic acid & 0.10 & $\underline{\mathrm{C}}_{18} \underline{\mathrm{H}}_{36} \underline{\mathrm{O}}_{2}$ & 284.50 & -4.7 \\
\hline 6 & 15.411 & Tetradecanoic acid & 0.26 & $\mathrm{C}_{14} \mathrm{H}_{28} \mathrm{O}_{2}$ & 228.37 & -4.5 \\
\hline 7 & 15.701 & Heptadecanolide & 0.22 & $\mathrm{C}_{17} \underline{\mathrm{H}}_{32} \mathrm{O}_{2}$ & 268.40 & -7.7 \\
\hline 8 & 15.799 & Cyclotetracosane & 0.43 & $\mathrm{C}_{24} \mathrm{H}_{48}$ & 336.60 & -8.7 \\
\hline 9 & 15.986 & Tetracosanoic acid & 1.22 & $\underline{\mathrm{C}_{24} \mathrm{H}_{48} \mathrm{O}_{2}}$ & 368.60 & -4.7 \\
\hline 10 & 16.060 & 6-Octadecenoic acid, (Z)- & 0.15 & $\mathrm{C}_{18} \underline{\mathrm{H}}_{34} \mathrm{O}_{2}$ & 282.50 & -4.2 \\
\hline 11 & 16.598 & Octadec-9-enoic acid & 0.06 & $\underline{\mathrm{C}_{18} \mathrm{H}_{34} \mathrm{O}_{2}}$ & 282.50 & -4.2 \\
\hline 12 & 17.994 & Cyclopentadecanone, 2-hydroxy- & 0.49 & $\underline{\mathrm{C}}_{15} \underline{\mathrm{H}}_{28} \underline{\mathrm{O}}_{2}$ & 240.38 & -7.9 \\
\hline 13 & 18.028 & 1-Octadecene & 0.53 & $\mathrm{C}_{18} \underline{\mathrm{H}}_{36}$ & 252.50 & -5.1 \\
\hline 14 & 18.487 & 3-Eicosene, (E)- & 0.20 & $\underline{\mathrm{C}_{20} \underline{\mathrm{H}}_{40}}$ & 280.50 & -4.6 \\
\hline 15 & 19.066 & 13-Tetradecen-1-ol acetate & 0.41 & $\underline{\mathrm{C}}_{16} \underline{\mathrm{H}}_{30} \underline{\mathrm{O}}_{2}$ & 254.41 & -4.5 \\
\hline 16 & 19.961 & Erucic acid & 1.32 & $\underline{\mathrm{C}}_{22} \mathrm{H}_{42} \mathrm{O}_{2}$ & 338.60 & -4.6 \\
\hline 17 & 20.109 & 5-Eicosene, (E)- & 0.64 & $\underline{\mathrm{C}}_{20} \underline{\mathrm{H}}_{40}$ & 280.50 & -4.8 \\
\hline Acarbose & - & - & - & 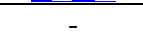 & - & -11.9 \\
\hline
\end{tabular}

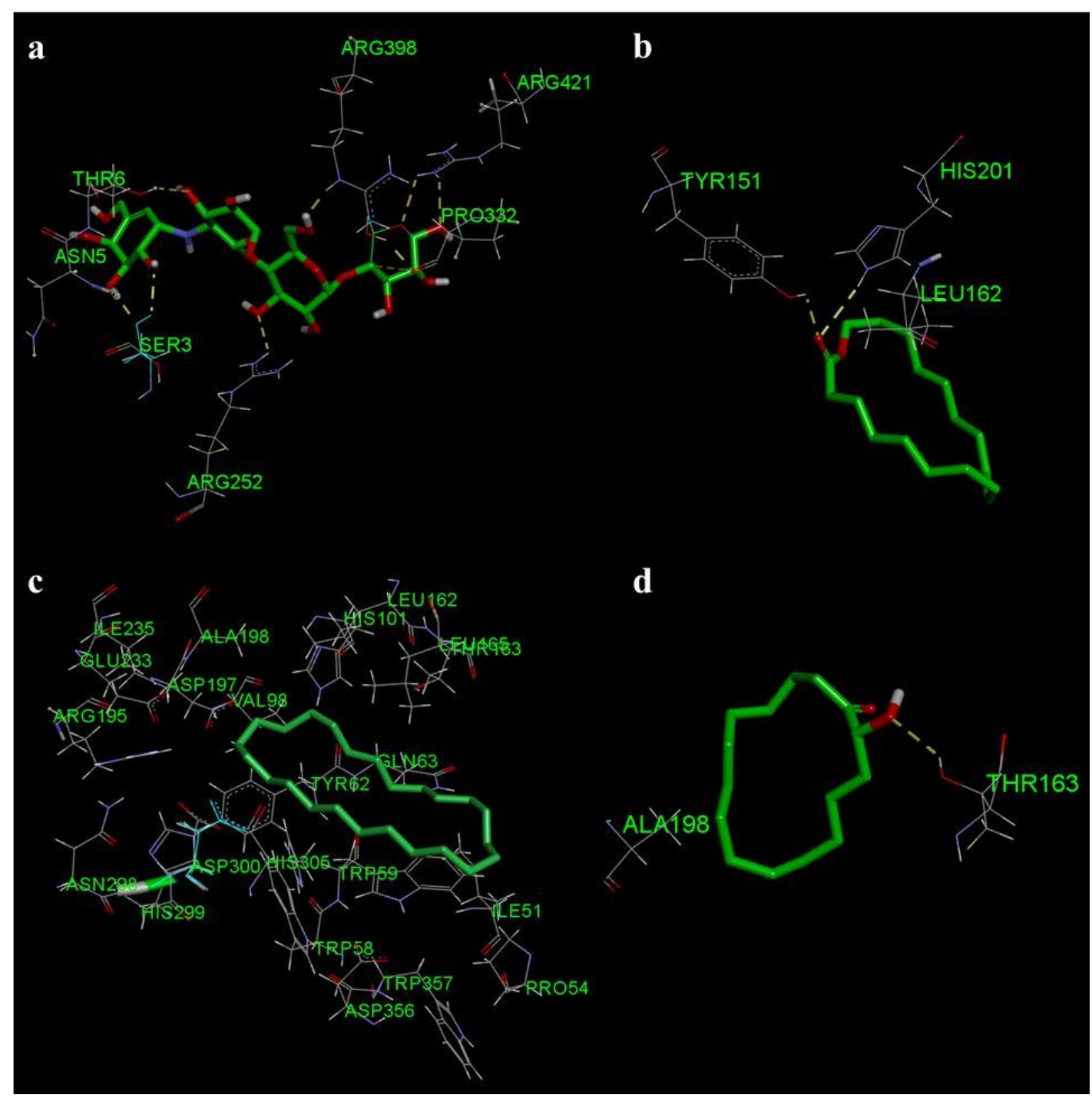

Figure 1. Molecular docking of selected compounds from Annona muricata into the binding site of $\alpha$-amylase (PDB ID: 5E0F), acarbose (a), compound 7 (b), compound 8 (c), and compound 12 (d) represented as sticks. The interacting residues are represented as lines. Hydrogen bonds are shown as yellow dashes. 


\subsection{Discussion.}

Diabetes is a disease affecting over 400 million adults, and therefore there is a need to discover a new drug to curb its scourge [27]. Most currently approved antidiabetic drugs have serious side effects and are costly $[5,13,28]$. In most traditional African and Asian settings, herbal formulations are used to manage diabetes and its complications [29, 30]. The use of herbal plants is gaining increased attention as they are deemed beneficial and atoxic. Researches that aim at drug discovery from plants fondly target specific pathways responsible for the pathogenesis of the disease [29]. In diabetes, inhibition of amylase is seen as one of the potent strategies; to minimize hydrolysis of carbohydrates, thereby managing glucose concentration in blood [30, 31].

In this present work, the phytochemical content, antioxidant activity, and $\alpha$-amylase inhibitory activity of extracts from Annona muricata were investigated. Phytochemicals present in plants are responsible for the antioxidant activity they elicit in vivo or in vitro and, by extension, disease treatment $[19,20,32,33]$. Our phytochemical analysis of the plant extracts revealed its richness in phenolic and flavonoid compounds. Different solvents extracted varying quantities of the phytochemicals, which could be attributed to the role of polarity in extraction efficiency. Other reports have shown that different plant parts of Annona muricata are rich in phytochemicals [17, 34]. However, this work presents a comparative approach and a guide for the choice of solvent where phenolic and flavonoid extract is desired. Oxidative stress has been implicated in most metabolic diseases that plague humans hence, the motivation to screen natural sources of antioxidants. Oxidative stress, resulting from increased levels of oxidants, decreased activity of antioxidant enzymes, and consequently increased levels of oxidatively damaged macromolecules, has also been implicated in the middle and advanced stages of diabetes mellitus [35]. From the results of this study, extracts of A. muricata possess antioxidant properties. In fact, antioxidant activity measured by the FRAP method revealed that the extracts were more potent antioxidants than Vitamin C. Similar results suggesting high antioxidant power have been reported in the literature $[15,36]$.

At the onset of diabetes, individuals present clinical symptoms such as sustained hyperglycemia [1,8]. Amylases are responsible for the breakdown of complex carbohydrates to monosaccharides; therefore, inhibition of amylases is a viable route of tackling hyperglycemia [6, 7, 37]. Amylase inhibiting drugs such as acarbose are some of the most commonly prescribed for the management of diabetes [7, 38]. In this study, the inhibitory activity of the extracts was tested against $\alpha$-amylase. All the extracts had $\alpha$-amylase inhibitory activity, albeit less active than acarbose. This result complements other reports on the antidiabetic effects of crude extracts of Annona muricata. Purification of the active components of the extracts could yield pure compounds with improved inhibitory activity [7, 39]. More so, pursuing further studies on the crude extract is justified owing to the anticipated safety of plantderived compounds.

To identify the active phytoconstituents in the extracts responsible for its antioxidant and $\alpha$-amylase inhibitory activity, GC-MS analysis was performed. Among the compounds identified were n-Decanoic acid, Oleic acid, 1-Eicosene, n-Hexadecanoic acid, Octadecanoic acid, Tetradecanoic acid, Heptadecanolide etc. The compounds identified have diverse biological properties [40]. It could be concluded that these compounds act synergistically to affect biological activity. Further insight into the possible role of the identified compounds in regulating glucose levels via pathways involving $\alpha$-amylase was given by in silico analysis [41, 
42]. Molecular docking analysis of compounds identified by GC-MS with $\alpha$-amylase showed significant interactions measured by binding energy. The compounds bound to the enzyme's active site forming stable interactions by hydrogen bonding and hydrophobic interactions with nearby amino acids [41-43]. Our results suggest that the extracts are rich in antioxidant phytochemicals that have amylase inhibitory activity.

\section{Conclusions}

The results of this study reveal that extracts of Annona muricata are promising sources of antioxidant compounds with antidiabetic properties. Based on the finding of the in silico analysis of GC-MS identified compounds, Heptadecanolide, Cyclotetracosane, Cyclopentadecanone 2-hydroxy- have the highest affinity for the active site of $\alpha$-amylase. These compounds can therefore be purified, tested in vivo. This work provides direction for future research in drug discovery for diabetes therapy.

\section{Funding}

This research received no external funding.

\section{Acknowledgments}

The authors are grateful for the assistance of the Laboratory staff of the Department of Biochemistry, Kogi State University, Nigeria.

\section{Conflicts of Interest}

The authors declare no conflict of interest.

\section{References}

1. Egan, A.M.; Dinneen, S.F. What is diabetes? Medicine 2019, 47, 1-4, https://doi.org/10.1016/j.mpmed.2018.10.002.

2. Sosibo, A.M.; Khathi, A. Pre-diabetes and COVID-19, could we be missing the silent killer? Experimental Biology and Medicine 2020, 246, 369-370, https://doi.org/10.1177/1535370220973451.

3. WHO, Diabetes. World Health Organization 2021, Available online: https://www.who.int/news-room/factsheets/detail/diabetes (accessed on 19 June, 2021).

4. Yousif, J.H.; Khan, F.R.; Zia, K.; Saadi, N.A. Analytical Data Review to Determine the Factors Impacting Risk of Diabetes in North Al-Batinah Region, Oman. International Journal of Environmental Research and Public Health 2021, 18, https://doi.org/10.3390/ijerph18105323.

5. Avwioroko, O.J.; Oyetunde, T.T.; Atanu, F.O.; Otuechere, C.A.; Anigboro, A.A.; Dairo, O.F.; Ejoh, A.S.; Ajibade, S.O.; Omorogie, M.O. Exploring the binding interactions of structurally diverse dichalcogenoimidodiphosphinate ligands with $\alpha$-amylase: Spectroscopic approach coupled with molecular docking. Biochemistry and Biophysics Reports 2020, 24, https://doi.org/10.1016/j.bbrep.2020.100837.

6. Avwioroko, O.J.; Anigboro, A.A.; Atanu, F.O.; Otuechere, C.A.; Alfred, M.O.; Abugo, J.N.; Omorogie, M.O. Investigation of the binding interaction of $\alpha$-amylase with Chrysophyllum albidum seed extract and its silver nanoparticles: A multi-spectroscopic approach. Chemical Data Collections 2020, 29, https://doi.org/10.1016/j.cdc.2020.100517.

7. Cardullo, N.; Muccilli, V.; Pulvirenti, L.; Cornu, A.; Pouységu, L.; Deffieux, D.; Quideau, S.; Tringali, C. Cglucosidic ellagitannins and galloylated glucoses as potential functional food ingredients with antidiabetic properties: a study of $\alpha$-glucosidase and $\alpha$-amylase inhibition. Food Chemistry 2020, 313, https://doi.org/10.1016/j.foodchem.2019.126099.

8. Wang, Z.; Wang, J.; Hu, J.; Chen, Y.; Dong, B.; Wang, Y. A comparative study of acarbose, vildagliptin and saxagliptin intended for better efficacy and safety on type 2 diabetes mellitus treatment. Life Sciences 2021, 274, https://doi.org/10.1016/j.lfs.2021.119069. 
9. Francis, O.A.; Oghenetega, J.A.; Omotayo, B.I.; Ojochenemi, E.Y. Metformin Potentiates the Antidiabetic Properties of Annona muricata and Tapinanthus globiferus Leaf Extracts in Diabetic Rats. Pharmacognosy Journal 2021, 13, 614-619, https://doi.org/10.5530/pj.2021.13.77.

10. Pang, G.-M.; Li, F.-X.; Yan, Y.; Zhang, Y.; Kong, L.-L.; Zhu, P.; Wang, K.-F.; Zhang, F.; Liu, B.; Lu, C. Herbal medicine in the treatment of patients with type 2 diabetes mellitus. Chinese Medical Journal 2019, 132, https://doi.org/10.1097/CM9.0000000000000006.

11. Venkatachalam, R.; Kalimuthu, K.; Chinnadurai, V.; Saravanan, M.; Radhakrishnan, R.; Shanmuganathan, R.; Pugazhendhi, A. Various solvent effects on phytochemical constituent profiles, analysis of antioxidant and antidiabetic activities of Hopea parviflora. Process Biochemistry 2020, 89, 227-232, https://doi.org/10.1016/j.procbio.2019.10.025.

12. Hedrington, M.S.; Davis, S.N. Considerations when using alpha-glucosidase inhibitors in the treatment of type 2 diabetes. Expert Opinion on Pharmacotherapy 2019, 20, 2229-2235, https://doi.org/10.1080/14656566.2019.1672660.

13. Anigboro, A.A.; Avwioroko, O.J.; Ohwokevwo, O.A.; Pessu, B.; Tonukari, N.J. Phytochemical profile, antioxidant, $\alpha$-amylase inhibition, binding interaction and docking studies of Justicia carnea bioactive compounds with $\alpha$-amylase. Biophysical Chemistry 2021, 269, https://doi.org/10.1016/j.bpc.2020.106529.

14. Avwioroko, O.J.; Anigboro, A.A.; Ejoh, A.S.; Atanu, F.O.; Okeke, M.A.; Tonukari, N.J. Characterization of $\alpha$-amylases isolated from Cyperus esculentus seeds (tigernut): Biochemical features, kinetics and thermal inactivation thermodynamics. Biocatalysis and Agricultural Biotechnology 2019, 21, https://doi.org/10.1016/j.bcab.2019.101298.

15. Anigboro, A.A.; Avwioroko, O.J.; Akeghware, O.; Tonukari, N.J. Anti-obesity, antioxidant and in silico evaluation of Justicia carnea bioactive compounds as potential inhibitors of an enzyme linked with obesity: Insights from kinetics, semi-empirical quantum mechanics and molecular docking analysis. Biophysical Chemistry 2021, 274, https://doi.org/10.1016/j.bpc.2021.106607.

16. Agu, K.C.; Eluehike, N.; Ofeimun, R.O.; Abile, D.; Ideho, G.; Ogedengbe, M.O.; Onose, P.O.; Elekofehinti, O.O. Possible antidiabetic potentials of Annona muricata (soursop): inhibition of $\alpha$-amylase and $\alpha$ glucosidase activities. Clinical Phytoscience 2019, 5, 1-13, https://doi.org/10.1186/s40816-019-0116-0.

17. Atanu, F.O.; Avwioroko, O.J.; Ilesanmi, O.B.; Oguche, M. Comparative Study of the Effects of Annona muricata and Tapinanthus globiferus Extracts on Biochemical Indices of Diabetic Rats. Pharmacognosy Journal 2019, 11, 1365-1370, https://doi.org/10.5530/pj.2019.11.211.

18. Shah, A.; Amini-Nik, S. The Role of Phytochemicals in the Inflammatory Phase of Wound Healing. International Journal of Molecular Sciences 2017, 18, https://doi.org/10.3390/ijms18051068.

19. Anigboro, A.; Avwioroko, O.; Ohwokevwo, O.; Nzor, J. Phytochemical constituents, antidiabetic and ameliorative effects of Polyalthia longifiola leaf extract in alloxan-induced diabetic rats. Journal of Applied Sciences Environmental Management 2018, 22, 993-998, https://doi.org/10.4314/jasem.v22i6.25.

20. Forni, C.; Facchiano, F.; Bartoli, M.; Pieretti, S.; Facchiano, A.; D’Arcangelo, D.; Norelli, S.; Valle, G.; Nisini, R.; Beninati, S.; Tabolacci, C.; Jadeja, R.N. Beneficial Role of Phytochemicals on Oxidative Stress and Age-Related Diseases. BioMed Research International 2019, 2019, https://doi.org/10.1155/2019/8748253.

21. Singleton, V.L.; Orthofer, R.; Lamuela-Raventós, R.M. Analysis of total phenols and other oxidation substrates and antioxidants by means of folin-ciocalteu reagent. Methods in Enzymology 1999, 299, 152-178, https://doi.org/10.1016/S0076-6879(99)99017-1.

22. Bourhia, M.; Laasri, F. E.; Moussa, S.I.; Ullah, R.; Bari, A.; Saeed Ali, S.; Kaoutar, A.; Haj Said, A.A.; El Mzibri, M.; Said, G. Phytochemistry, antioxidant activity, antiproliferative effect, and acute toxicity testing of two Moroccan Aristolochia species. Evidence-Based Complementary and Alternative Medicine 2019, 2019, https://doi.org/10.1155/2019/9710876.

23. Benzie, I.F.; Strain, J. Ferric reducing/antioxidant power assay: direct measure of total antioxidant activity of biological fluids and modified version for simultaneous measurement of total antioxidant power and ascorbic acid concentration. Methods in Enzymology 1999, 299, 15-27, https://doi.org/10.1016/S00766879(99)99005-5.

24. Arogba, S.S. Effect of Processing on Antioxidant Activity of Conventional Mango (Mangifera indica) Seed. Journal of Environmental Science, Toxicology Food Technology 2015, 9, 50-55.

25. Blois, M.S. Antioxidant Determinations by the Use of a Stable Free Radical. Nature 1958, 181, 1199-1200, https://doi.org/10.1038/1811199a0.

26. Adefegha, S.A.; Oboh, G. In vitro inhibition activity of polyphenol-rich extracts from Syzygium aromaticum (L.) Merr. \& Perry (Clove) buds against carbohydrate hydrolyzing enzymes linked to type 2 diabetes and Fe2+-induced lipid peroxidation in rat pancreas. Asian Pacific Journal of Tropical Biomedicine 2012, 2, 774781, https://doi.org/10.1016/S2221-1691(12)60228-7.

27. WHO, Guidelines on second-and third-line medicines and type of insulin for the control of blood glucose levels in non-pregnant adults with diabetes mellitus. World Health Organization 2018, Available online: https://apps.who.int/iris/bitstream/handle/10665/272433/9789241550284-eng.pdf (last accessed on 19 June, 2021). 
28. Hossain, M. A.; Pervin, R., Current antidiabetic drugs: review of their efficacy and safety. Nutritional and Therapeutic Interventions for Diabetes and Metabolic Syndrome 2018, 455-473, https://doi.org/10.1016/B978-0-12-812019-4.00034-9.

29. Tran, N.; Pham, B.; Le, L. Bioactive Compounds in Antidiabetic Plants: From Herbal Medicine to Modern Drug Discovery. Biology 2020, 9, https://doi.org/10.3390/biology9090252.

30. Ibrahim, S.R.M.; Mohamed, G.A.; Khayat, M.T.A.; Ahmed, S.; Abo-Haded, H. $\alpha$-Amylase inhibition of xanthones from Garcinia mangostana pericarps and their possible use for the treatment of diabetes with molecular docking studies. Journal of Food Biochemistry 2019, 43, https://doi.org/10.1111/jfbc.12844.

31. Nasab, S.B.; Homaei, A.; Karami, L. Kinetic of $\alpha$-amylase inhibition by Gracilaria corticata and Sargassum angustifolium extracts and zinc oxide nanoparticles. Biocatalysis and Agricultural Biotechnology 2020, 23, https://doi.org/10.1016/j.bcab.2019.101478.

32. Arora, I.; Sharma, M.; Tollefsbol, T.O. Combinatorial Epigenetics Impact of Polyphenols and Phytochemicals in Cancer Prevention and Therapy. International Journal of Molecular Sciences 2019, 20, https://doi.org/10.3390/ijms20184567.

33. Moreno-Valdespino, C.A.; Luna-Vital, D.; Camacho-Ruiz, R.M.; Mojica, L. Bioactive proteins and phytochemicals from legumes: Mechanisms of action preventing obesity and type-2 diabetes. Food Research International 2020, 130, https://doi.org/10.1016/j.foodres.2019.108905.

34. Rubio-Melgarejo, A.; Balois-Morales, R.; Palomino-Hermosillo, Y. A.; López-Guzmán, G. G.; RamírezRamírez, J.C.; Cervantes-García, E.; Villalobos-Rosario, B.J.; Bautista-Rosales, P.U. Phytochemical and Antioxidant Dynamics of the Soursop Fruit (Annona muricata L.) in response to Colletotrichum spp. Journal of Food Quality 2020, 2020, https://doi.org/10.1155/2020/3180634.

35. Huang, M.; Liu, S.; Fu, L.; Jiang, X.; Yang, M. Bisphenol A and its analogues bisphenol S, bisphenol F and bisphenol AF induce oxidative stress and biomacromolecular damage in human granulosa KGN cells. Chemosphere 2020, 253, https://doi.org/10.1016/j.chemosphere.2020.126707.

36. Cheng, Y.; Quan, W.; He, Y.; Qu, T.; Wang, Z.; Zeng, M.; Qin, F.; Chen, J.; He, Z. Effects of postharvest irradiation and superfine grinding wall disruption treatment on the bioactive compounds, endogenous enzyme activities, and antioxidant properties of pine (Pinus yunnanensis) pollen during accelerated storage. $L W T$ 2021, 144, https://doi.org/10.1016/j.lwt.2021.111249.

37. Smina, C.S.; Lalitha, P.; Nagabhushana, H.; Sharma, S.C. Terminalia bellirica dried fruit and seed extract offers alpha-amylase inhibitory potential in tackling diabetes. Applied Nanoscience 2020, 10, 4325-4339, https://doi.org/10.1007/s13204-020-01549-X.

38. Oboh, G.; Ogunbadejo, M.D.; Ogunsuyi, O.B.; Oyeleye, S.I. Can gallic acid potentiate the antihyperglycemic effect of acarbose and metformin? Evidence from streptozotocin-induced diabetic rat model. Archives of Physiology and Biochemistry 2020, 24, 1-9, https://doi.org/10.1080/13813455.2020.1716014.

39. Qin, G.; Xu, W.; Liu, J.; Zhao, L.; Chen, G. Purification, characterization and hypoglycemic activity of glycoproteins obtained from pea (Pisum sativum L.). Food Science and Human Wellness 2021, 10, 297-307, https://doi.org/10.1016/j.fshw.2021.02.021.

40. Ben Lataief, S.; Zourgui, M.-N.; Rahmani, R.; Najjaa, H.; Gharsallah, N.; Zourgui, L. Chemical composition, antioxidant, antimicrobial and cytotoxic activities of bioactive compounds extracted from Opuntia dillenii cladodes. Journal of Food Measurement and Characterization 2021, 15, 782-794, https://doi.org/10.1007/s11694-020-00671-2.

41. Ghaedi, N.; Pouraboli, I.; Askari, N. Antidiabetic Properties of Hydroalcoholic Leaf and Stem Extract of Levisticum officinale: An implication for $\alpha$-amylase Inhibitory Activity of Extract Ingredients through Molecular Docking. Iranian Journal of Pharmaceutical Research 2020, 19, 231-250, https://doi.org/10.22037/ijpr.2020.15140.12901.

42. Hussain, S.; Taha, M.; Rahim, F.; Hayat, S.; Zaman, K.; Iqbal, N.; Selvaraj, M.; Sajid, M.; Bangesh, M.A.; Khan, F.; Khan, K.M.; Uddin, N.; Shah, S.A.A.; Ali, M. Synthesis of benzimidazole derivatives as potent inhibitors for $\alpha$-amylase and their molecular docking study in management of type-II diabetes. Journal of Molecular Structure 2021, 1232, https://doi.org/10.1016/j.molstruc.2021.130029.

43. Nadeem, M.; Mumtaz, M.W.; Danish, M.; Rashid, U.; Mukhtar, H.; Irfan, A.; Anwar, F.; Saari, N. UHPLCQTOF-MS/MS metabolites profiling and antioxidant/antidiabetic attributes of Cuscuta reflexa grown on Casearia tomentosa: exploring phytochemicals role via molecular docking. International Journal of Food Properties 2020, 23, 918-940, https://doi.org/10.1080/10942912.2020.1764578. 